\title{
Effects of di- $n$-butyl phthalate on mycorrhizal and non-mycorrhizal cowpea plants
}

\author{
S.-G. WANG*1, X.-G. LIN**, R. YIN** and Y.-L. HOU* \\ Research Center for Eco-Environmental Sciences, Chinese Academy of Sciences, Beijing 100085, China* \\ Institute of Soil Sciences, Chinese Academy of Sciences, Nanjing 210008, China**
}

\begin{abstract}
Cowpea (Vigna sinensis L.) plants were inoculated with arbuscular mycorrhizal fungus (Acaulospora laevis) to investigate the effects of different concentrations of di-n-butyl phthalate (DBP; 0,10 , and $100 \mathrm{mg} \mathrm{kg}^{-1}$ ) added to soil on their growth. Mycorrhizal plants were less affected by high concentration of DBP (100 mg kg $\mathrm{g}^{-1}$ ) than non-mycorrhizal ones. Also the uptake and transformation of DBP by mycorrhizal plants differed from that of non-mycorrhizal plants.
\end{abstract}

Additional key words: Acaulospora laevis, root and shoot biomass, Vigna sinensis.

Di- $n$-butyl phthalate (DBP) is one of the commercial phthalate esters (PAEs), which are important and popular additives in many industrial products. However, PAEs are also environmental pollutants due to their hepatotoxicity (Seth 1982), mutagenicity (Kozumbo et al. 1982) and carcinogenicity (Kluwe 1982). Numerous studies have been reported on the biodegradation of PAEs in natural water (Taylor et al. 1981, Johnson and Heitkamp 1984, Walker et al. 1984), wastewater (Nozawa and Maruyama 1988, Wang et al. 1996) and soil (Inman et al. 1984, Wang et al. 1997). However, only few reports deal with the fate of PAEs in the soil-plant systems (Shea et al. 1982, Schmitzer et al. 1988, Yin et al. 2003), and to our knowledge no studies have been conducted in the soilmycorrhizal plant systems.

Therefore, we chose DBP which is the most frequently identified PAEs in diverse environmental samples, as representatives of PAEs and designed this experiment to study the responses of mycorrhizal and non-mycorrhizal plants to the different concentrations of DBP added to soil.

Soil was collected from a farmland in Qinlin town (Nanjing, China), with $\mathrm{pH} 6.95$, total $\mathrm{N} 1.6 \mathrm{~g} \mathrm{~kg}^{-1}$, total $\mathrm{P}$
$1.47 \mathrm{~g} \mathrm{~kg}^{-1}$, total $\mathrm{K} 18.4 \mathrm{~g} \mathrm{~kg}^{-1}$, available P $50.5 \mathrm{mg} \mathrm{kg}^{-1}$, soluble $\mathrm{N} 23.9 \mathrm{mg} \mathrm{kg}^{-1}$, and initial DBP $2.3 \mathrm{mg} \mathrm{kg}^{-1}$. Air-' dried soil was passed through a $2 \mathrm{~mm}$ mesh, mixed, and artificially contaminated with increasing concentrations of DBP $\left(0,10\right.$, and $\left.100 \mathrm{mg} \mathrm{kg}^{-1}\right)$. Soil moisture was adjusted to $60 \%$ of its field capacity with sterile distilled water.

Arbuscular mycorrhiza (AM) fungus Acaulospora laevis was isolated from the Ecological Experimental Station of Red Soil (Yingtan, China) and propagated on white clover (Trifolium repens L) in a greenhouse for 4 months. Colonized clover roots and adhering soils were used as inoculum. Mycorrhizal inoculum was uniformly mixed with the soil in pots. Non-mycorrhizal treatments received the same amounts of autoclaved fungal agents.

Two 3-d-old cowpea seedlings were transferred to each pot containing $1500 \mathrm{~g}$ soils. Pots were kept in a growth chamber with a temperature $22 / 18^{\circ} \mathrm{C}$ (day/night), and a 16-h photoperiod at irradiance of $480 \mu \mathrm{mol} \mathrm{m} \mathrm{m}^{-2} \mathrm{~s}^{-1}$ (PAR; $400 \cdot 700 \mathrm{~nm}$ ). The plants were harvested 20, 40 , and $60 \mathrm{~d}$ after transplanting, three replicates each time. The shoots were cut just above the soil surface. The roots were recovered by washing with distilled water. From

Received 27 January 2003, accepted 17 June 2003.

Abbreviations: DBP- di-n-butyl phthalate; PAEs - phthalate esters; AM - arbuscular mycorrhiza; NM - non-mycorrhizal; $\mathrm{M}$ - mycorrhizal; PAR - photosynthetically active radiation.

Acknowledgements: This study was supported by the National Key Basic Research Project of China (No. G1999011806). We appreciate the constructive comments from anonymous referee and Prof. Y.G. Zhu for improving the English manuscript.

${ }^{1}$ Corresponding author, fax: (+86) 10 62923563, e-mail: shgwang2002@yahoo.com.cn. 
each pot a sample of $c a .1 \mathrm{~g}$ fresh root mass was taken for the measurement of mycorrhizal colonization. The shoots and other roots were oven dried at $70^{\circ} \mathrm{C}$ and then ground for DBP analysis.

Mycorrhizal colonization rate was evaluated according to Koske and Gemma (1989). Analysis of DBP in shoot and root was performed using gas chromatography (Yin et al. 2003). Briefly, ground plant samples $(2 \mathrm{~g})$ were extracted in $60 \mathrm{~cm}^{3}$ mixture consisting of acetone and petroleum ether $(1: 1, \mathrm{v} / \mathrm{v})$. Splitting the extracts into two phases by adding $100 \mathrm{~cm}^{3} 6 \%$ sodium sulfate solution, the organic layer was transferred to a Kuderna-Danish apparatus, and allowed to evaporate until the extract volume was reduced to $2 \mathrm{~cm}^{3}$. The concentrated sample was cleaned on a column of activated Florist PR 60/100 (Silica Company, Berkeley, USA). These samples were then analyzed by gas chromatography ( $G C-9 A$ with a flame ionization detector, Shimadzu, Tokyo, Japan). Column material used was $10 \% S E-30$ on chromosorb $W H P$ packed in a stainless column ( $2 \mathrm{~m}$, i.d. $4 \mathrm{~mm})$. Conditions were as follows: oven $240{ }^{\circ} \mathrm{C}$; detector $300{ }^{\circ} \mathrm{C}$; nitrogen gas, $40 \mathrm{~cm}^{3} \mathrm{~min}^{-1}$. Two $\mathrm{mm}^{3}$ of the solutions were injected and peak heights were compared with those standard solutions with known concentrations. The detection limit was $1 \mathrm{ng}$.
The percentage of mycorrhizal colonization decreased slightly at $10 \mathrm{mg} \mathrm{kg}^{-1}$ DBP compared with that at no addition of DBP, but it significantly decreased at $100 \mathrm{mg} \mathrm{kg}^{-1} \mathrm{DBP}$ at the early growth stage (before $20 \mathrm{~d}$ ) (Table 1). This could be due to the inhibition of spore germination. Also the length of hyphae produced by AM fungi in soil with $100 \mathrm{mg} \mathrm{kg}{ }^{-1} \mathrm{DBP}$ was less than that in soil with 0 or $10 \mathrm{mg} \mathrm{kg}^{-1}$ DBP (data not shown).

Table 1. Frequency [\%] of non-mycorrhizal (NM) and mycorrhizal $(\mathrm{M})$ roots of cowpea plants grown in soil artificially polluted with different concentrations of DBP $(0,10$. and $\left.100 \mathrm{mg} \mathrm{kg}^{-1}\right)$. Means $\pm \mathrm{SE}, n=3$. Different letters in a column indicate significant difference between $N M$ and $M$ treatments at $P<0.05$ determined by Duncan's test.

\begin{tabular}{lllll}
\hline \multicolumn{2}{l}{$\mathrm{DBP}\left[\mathrm{mg} \mathrm{kg}^{-1}\right]$} & $20 \mathrm{~d}$ & $40 \mathrm{~d}$ & $60 \mathrm{~d}$ \\
\hline 0 & $\mathrm{NM}$ & $14.0 \pm 2.00 \mathrm{a}$ & $16.0 \pm 1.76 \mathrm{a}$ & $16.0 \pm 0.88 \mathrm{a}$ \\
& $\mathrm{M}$ & $32.5 \pm 2.81 \mathrm{~b}$ & $34.0 \pm 2.01 \mathrm{~b}$ & $36.0 \pm 2.95 \mathrm{~b}$ \\
10 & $\mathrm{NM}$ & $16.0 \pm 1.46 \mathrm{a}$ & $16.0 \pm 0.85 \mathrm{a}$ & $17.5 \pm 1.62 \mathrm{a}$ \\
& $\mathrm{M}$ & $30.0 \pm 3.20 \mathrm{~b}$ & $30.0 \pm 0.00 \mathrm{c}$ & $35.0 \pm 2.34 \mathrm{~b}$ \\
100 & $\mathrm{NM}$ & $13.0 \pm 1.47 \mathrm{a}$ & $14.0 \pm 1.09 \mathrm{a}$ & $15.0 \pm 0.85 \mathrm{a}$ \\
& $\mathrm{M}$ & $24.5 \pm 0.97 \mathrm{c}$ & $31.5 \pm 3.38 \mathrm{bc}$ & $48.0 \pm 4.12 \mathrm{c}$ \\
\hline
\end{tabular}

Table 2. Effects of mycorrhizal infection and applications of different concentrations of DBP $\left(0,10\right.$, and $\left.100 \mathrm{mg} \mathrm{kg}^{-1}\right)$ on shoot and root biomass of non-mycorrhizal $(\mathrm{NM})$ and mycorrhizal $(\mathrm{M})$ cowpea plants. Means $\pm \mathrm{SE}, n=3$. Different letters in a column indicate significant difference between $\mathrm{NM}$ and $\mathrm{M}$ treatments at $P<0.05$.

\begin{tabular}{|c|c|c|c|c|c|c|c|}
\hline \multicolumn{2}{|c|}{$\mathrm{DBP}\left[\mathrm{mg} \mathrm{kg}^{-1}\right]$} & \multicolumn{2}{|c|}{ Shoot dry mass [g plant ${ }^{-1}$ ] } & \multicolumn{4}{|c|}{ Root dry mass [g plant $\left.{ }^{-1}\right]$} \\
\hline & & $20 \mathrm{~d}$ & $40 \mathrm{~d}$ & $60 d$ & $20 \mathrm{~d}$ & $40 \mathrm{~d}$ & $60 \mathrm{~d}$ \\
\hline \multirow[t]{2}{*}{0} & NM & $1.24 \pm 0.11 \mathrm{a}$ & $3.06 \pm 0.22 \mathrm{a}$ & $4.60 \pm 0.32 a$ & $0.63 \pm 0.02 a$ & $0.80 \pm 0.02 \mathrm{a}$ & $1.09 \pm 0.12 \mathrm{a}$ \\
\hline & $\mathrm{M}$ & $1.83 \pm 0.05 b$ & $4.52 \pm 0.19 b$ & $6.79 \pm 0.60 b$ & $0.72 \pm 0.05 b$ & $0.96 \pm 0.05 b$ & $1.29 \pm 0.06 \mathrm{~b}$ \\
\hline \multirow[t]{2}{*}{10} & NM & $1.17 \pm 0.10 \mathrm{a}$ & $2.96 \pm 0.18 a$ & $4.02 \pm 0.21 \mathrm{c}$ & $0.56 \pm 0.06 \mathrm{ac}$ & $0.74 \pm 0.03 c$ & $1.03 \pm 0.04 \mathrm{a}$ \\
\hline & $\mathrm{M}$ & $1.70 \pm 0.14 b$ & $4.36 \pm 0.35 b$ & $6.38 \pm 0.89 b$ & $0.68 \pm 0.02 b$ & $0.88 \pm 0.02 \mathrm{a}$ & $1.14 \pm 0.10 \mathrm{ab}$ \\
\hline \multirow[t]{2}{*}{100} & NM & $1.02 \pm 0.04 \mathrm{c}$ & $2.60 \pm 0.12 \mathrm{~d}$ & $4.42 \pm 0.16 \mathrm{a}$ & $0.47 \pm 0.04 c$ & $0.75 \pm 0.05 c$ & $0.93 \pm 0.05 \mathrm{c}$ \\
\hline & $\mathrm{M}$ & $1.30 \pm 0.18 \mathrm{a}$ & $3.76 \pm 0.11 \mathrm{c}$ & $7.70 \pm 0.29 \mathrm{~d}$ & $0.59 \pm 0.05 a$ & $0.96 \pm 0.04 b$ & $1.53 \pm 0.15 \mathrm{~d}$ \\
\hline
\end{tabular}

Table 3. Uptake of DBP by non-mycorrhizal (NM) and mycorrhizal (M) cowpea plants grown in soils added with different concentrations of DBP $\left(0,10\right.$, and $\left.100 \mathrm{mg} \mathrm{kg}^{-1}\right)$. Means $\pm \mathrm{SE}, n=3$. Different letters in a column indicate significant difference between NM and M treatments at $P<0.01$. n.d. - not detectable, indicates DBP concentration was under detection limit $(1 \mathrm{ng})$ or zero.

\begin{tabular}{cllrrrrr}
\hline \multirow{2}{*}{ DBP [mg kg $\left.{ }^{-1}\right]$} & \multicolumn{2}{l}{ Shoot DBP concentration [mg kg $\left.{ }^{-1}(\mathrm{~d} . \mathrm{m}).\right]$} & \multicolumn{3}{l}{ Root DBP concentration [mg kg $\left.{ }^{-1}(\mathrm{~d} . \mathrm{m}).\right]$} \\
& & $20 \mathrm{~d}$ & $40 \mathrm{~d}$ & $60 \mathrm{~d}$ & $20 \mathrm{~d}$ & $40 \mathrm{~d}$ & $60 \mathrm{~d}$ \\
\hline \multirow{2}{*}{0} & $\mathrm{NM}$ & n.d*. & $5.82 \pm 0.43 \mathrm{a}$ & $6.74 \pm 0.21 \mathrm{a}$ & $26.75 \pm 2.12 \mathrm{a}$ & $16.08 \pm 1.19 \mathrm{a}$ & $9.12 \pm 0.29 \mathrm{a}$ \\
& $\mathrm{M}$ & $3.68 \pm 0.22 \mathrm{a}$ & $6.01 \pm 0.62 \mathrm{a}$ & $6.20 \pm 0.33 \mathrm{a}$ & $17.46 \pm 0.66 \mathrm{~b}$ & $10.44 \pm 0.61 \mathrm{~b}$ & $6.35 \pm 0.38 \mathrm{~b}$ \\
10 & $\mathrm{NM}$ & n.d. & $11.43 \pm 0.39 \mathrm{~b}$ & $14.77 \pm 1.05 \mathrm{~b}$ & $70.69 \pm 4.67 \mathrm{c}$ & $33.90 \pm 1.32 \mathrm{c}$ & $20.98 \pm 1.34 \mathrm{c}$ \\
& $\mathrm{M}$ & $7.25 \pm 0.30 \mathrm{~b}$ & $11.43 \pm 0.59 \mathrm{~b}$ & $11.26 \pm 0.78 \mathrm{c}$ & $41.04 \pm 2.56 \mathrm{~d}$ & $24.60 \pm 0.64 \mathrm{~d}$ & $13.96 \pm 0.88 \mathrm{~d}$ \\
100 & $\mathrm{NM}$ & $3.40 \pm 0.18 \mathrm{a}$ & $16.30 \pm 0.42 \mathrm{c}$ & $19.78 \pm 1.43 \mathrm{~d}$ & $123.67 \pm 4.98 \mathrm{e}$ & $60.92 \pm 2.85 \mathrm{e}$ & $35.04 \pm 2.26 \mathrm{e}$ \\
& $\mathrm{M}$ & $8.31 \pm 0.21 \mathrm{c}$ & $14.78 \pm 0.37 \mathrm{~d}$ & $14.35 \pm 0.91 \mathrm{~b}$ & $99.89 \pm 5.02 \mathrm{f}$ & $38.74 \pm 1.34 \mathrm{c}$ & $24.37 \pm 1.05 \mathrm{c}$ \\
\hline
\end{tabular}


Shoot and root biomass significantly decreased due to DBP treatment, especially at $100 \mathrm{mg} \mathrm{kg}^{-1} \mathrm{DBP}$ (Table 2). The results did not agree with those of Shea et al. (1982), who found that maize heights and shoot mass were not significantly reduced at $200 \mathrm{mg} \mathrm{kg}^{-1} \mathrm{DBP}$ in soil, and was significantly inhibited at $2000 \mathrm{mg} \mathrm{kg}^{-1} \mathrm{DBP}$. The difference in plants response to DBP concentrations was associated with difference in sensitivity of plants to DBP (Cai et al. 1994).

Inoculation with AM fungi significantly alleviated the inhibition effect of DBP on plant growth and increased shoot and root biomass compared with non-inoculated plants (Table 2), which indicated AM could promote plant growth in DBP-contaminated soil. Especially after $40 \mathrm{~d}$, shoot and root biomass of mycorrhizal plants increased markedly, but shoot and root biomass of nonmycorrhizal plants increased slightly. Although shoot biomass of mycorrhizal plants was higher than that of non-mycorrhizal plants, DBP concentration in the shoot

\section{References}

Cai. Y.Q. Tang. G.C.. Wang. S.L., Qian, X.Q., Feng, K.: [Sensitivity of crops to phthalate ester.] - Rural Ecoenvironm. 10: 29-32. 1994. [In Chin.]

Inman. I.C.. Strachan. S.D.. Sommer, L.E., Nelson. D.W.: The decompostion of phthlater esters in soil. - J. environ. Sci. Health Ser. B 19: 245-257, 1984

Johnson, B.T., Heitkamp, M.A.: Environmental and chemical factors influencing the biodegradation of phthalic acid esters in freshwater sediments. - Environ. Pollut. Ser. B 8: 101 118, 1984.

Kluwe. W.M. Mcconnell, E.E., Huff, J.E., Haseman, J.K., Douglas. J.F. Hartwell, W.V.: Carcinogenicity testing of phthalater esters and relaterd compounds by the National Toxicology Programms and the National Cancer Institute. Environ. Health Perspectives 45: 129-133, 1982.

Koske, R.E., Gemma, J.N.: A modified procedure for staining roots to detect VA mycorrhizas. - Mycology 92: 486-505, 1989.

Kozumbo, W.J., Kroll, R., Rubin, R.J.: Assessment of mutagenicity of phthalater esters. - Environ. Health Perspectives 45: 103-110, 1982.

Nozawa. T., Maruyama, Y.: Anaerobic metabolism of phthalater and other aromatic compounds by a denitrifying bacterium. - J. Bacteriol. 170: 5778-5784, 1988. of mycorrhizal plants was higher than that of nonmycorrhizal plant at the early growth stage (before $20 \mathrm{~d}$ ) (Table 3), which indicated that more DBP was uptake by the mycorrhizal seedlings. It was surprising, however, that the DBP translocation weakened after the mycorrhizal seedlings grew up (after $40 \mathrm{~d}$ ). This is why DBP concentration in the mycorrhizal shoots increased only by $1.5 \%$ from $40 \mathrm{~d}$ to $60 \mathrm{~d}$, while by $29.2 \%$ in the non-mycorrhizal shoots (Table 3). In roots, DBP concentrations in the mycorrhizal plants were always lower than that in the non-mycorrhizal plants. Tissue dilution also decreased DBP concentrations in the mycorrhizal shoot and root, because shoot and root biomass of mycorrhizal plants was significantly higher than that of non-mycorrhizal plants (Table 2).

In summary, mycorrhizal plants were less affected by high concentration of DBP, and had special mechanisms to control uptake and transformation of DBP, but the mechanisms need further investigations.

Schmitzer, J.L.. Scheunert, I., Korte. F.: Fate of bis(2ethylhexyl) $\left[{ }^{14} \mathrm{C}\right]$ phthalate in laboratory and outdoor soilplant systems. - I. agr. Food Chem. 36: 210-215, 1988.

Seth, P.K.: Hepatic effects of phthalater esters. - Environ. Health Perspectives 45: 27-34, 1982.

Shea, P.J., Weber, J.B., Overcash, M.R.: Uptake and phytotoxicity of di-n-butyl phthalate in corn (Zea mays). Bull. Environ. Contam. Toxicol. 29: 153-158, 1982.

Taylor, B.F., Curry, R.W., Corcoran, E.F.: Potential for biodegradation of phthalic acid esters in marine regions. Appl. Environ. Microbiol. 42: 590-595, 1981.

Walker, W.W., Cripe, C.R., Pritchard, P.H., Bourguin, A.W.: Dibutyl phthalater degradation in esturine and fresh water sites. - Chemosphere 13: 1283-1294, 1984.

Wang, J.L., Liu, P., Qian, Y.: Biodegradation of phthalic acid esters by acclimated activated sludge. - Environ. Int. 22: 737-741, 1996.

Wang, J.L., Liu, P., Shi, H.C., Qian, Y.: Biodegradation of phthalic acid ester in soil by indigenous and introduced microorganism. - Chemosphere 35: 1747-1754, 1997.

Yin, R., Lin, X.G., Wang, S.G., Zhang, H.Y.: Influence of DBP/DEHP in vegetable garden soil on quality of Capsicum fruit. - Chemosphere 50: 801-805. 2003. 